九州大学学術情報リポジトリ

Kyushu University Institutional Repository

\title{
Development of Impact-Cell-Mill (ICM) and Its Mechanical Characteristics
}

Hayakawa, Isao

Laboratory of Food Technology, Faculty of Agriculture, Kyushu University

Nomura, Danj i

Laboratory of Food Technology, Faculty of Agriculture, Kyushu University

https://doi.org/10.5109/22838

出版情報：九州大学大学院農学研究院紀要. 17 (3/4)，pp. 289-302，1973-10. Kyushu University バージョン：

権利関係 : 


\title{
Development of Impact-Cell-Mill (ICM) and Its Mechanical Characteristics
}

\author{
Isao Hayakawa and Danji Nomura \\ Laboratory of Food Technology, Faculty of Agriculture, \\ Kyushu University, Fukuoka
}

(Received June 19, 1973)

\begin{abstract}
A machine was named Impact-Cell-Mill (ICM) which has been developed for the destruction of single cell microbe such as yeast and chlorella. We have been come to many difficult problems in the nozzle, disk, valve, pressure sealing materials and mechanical technique, etc.

Teflon gave good results as the materials for sealing the machine and four or more sheets of seal packing were necessary for durability of plungers which made high pressure as $600-800 \mathrm{~kg} / \mathrm{cm}^{2}$. Sintered hard alloy was suitable as the materials of a nozzle, disks, valves.

In respect of the angle of the nozzle, 15 degrees was superior to 55 degrees. The nozzle with a polished surface showed good results. Baker's yeast could be crushed about $33-44 \%$ passing once through ICM under the condition of $600-800 \mathrm{~kg} / \mathrm{cm}^{2}$ as spouting pressure. The crushing energy at that time about $24-26 \mathrm{cal} / \mathrm{g}$.
\end{abstract}

\section{INTRODUCTION}

Some necessities of researching on utilizations of protein from single cell microbe have been pointed out these days (Laine, 1967; Yamada, 1968 ; Kurosawa, 1969). Yeast, bacteria and algae such as chlorella are included in the single cell microbe. As they have a tough cell wall, they have been inefficient for the digestion of single cells, extraction of protein and utilization of the cell contents. When the single cell microbe will be used as a feed directly or used as an extracting ingredient such as protein, the cell wall should be destroyed and removed. We think available to destroy the cell wall and study to develop a machine to destroy the single cells, The single cells could be converted into food or as a feed after this research. As to research regarding the extraction of single cell protein, we are familiar with the chemical methods such as urea or alkali treatment (Mitsuda et al., 1964 ; Mitsuda et al., 1967), with the physical methods such as super sonics (ultra sonics) and depressure by super high pressure. But, when large scale treatment is required successively, these methods are not economical.

There are many methods for destruction of substance, but from the viewpoint of destruction energy, one of the, most effective methods is the utilization of impulsion power which is superior to the others, especially when destroying a tiny substance such as a single cell.

The methods providing for impulsion prower are : 
1) Jet mill method

2) Microniser method

3) Jet mizer method

4) Liquid jet method
(Miwa et al, 1971)

(Fujita et al, 1968)

(Fujita et al, 1963)

(Okuda, 1971)

We have tried to develop a special mill equipped with liquid jet generator based on fluid jet application. This machine is named Impact-Cell-Mill (ICM). Having developed a trial model based on ICM, we have pursued its physical characteristics. We have figured out the increasing of pressure during operation, shape of nozzle, problem of its surface treatment and consumption of input energy, since jet is liable to be affected in characters by surroundings. The results of the experiments are reported in this paper.

\section{EXPERIMENTAL METHODS}

\section{Experimental device}

The diagrammatic sketch of ICM is shown in Fig. 1. The weight of this trial model is about $500 \mathrm{~kg}$, and composed of a high pressure injector and plunger power units. The power units consist of a motor $(5 \mathrm{ps})$, reduction gears, a crank shaft and connecting rods. The high pressure is produced by driving the high pressure units with connecting rods.

The materials of the high pressure units are SUS 27, which has excellent anticorrosion properties.

Since the jet pressure is as high as $600400 \mathrm{~kg} / \mathrm{cm}^{2}$, this model has local stress concentration. The use of block steel in such a high pressure is to avoid the damage to the apparatus. Steel pipe is never used. The trial model is built in three pairs of (4)-(7) unit of Fig. 1. One plunger is fortified by rotator angle $2 \pi / 3$ of the driving crank shaft. The plunger is $15 \mathrm{~mm}$ in diameter, $50 \mathrm{~mm}$ in stroke, and the crank shaft speed is $118 \mathrm{rpm}$.

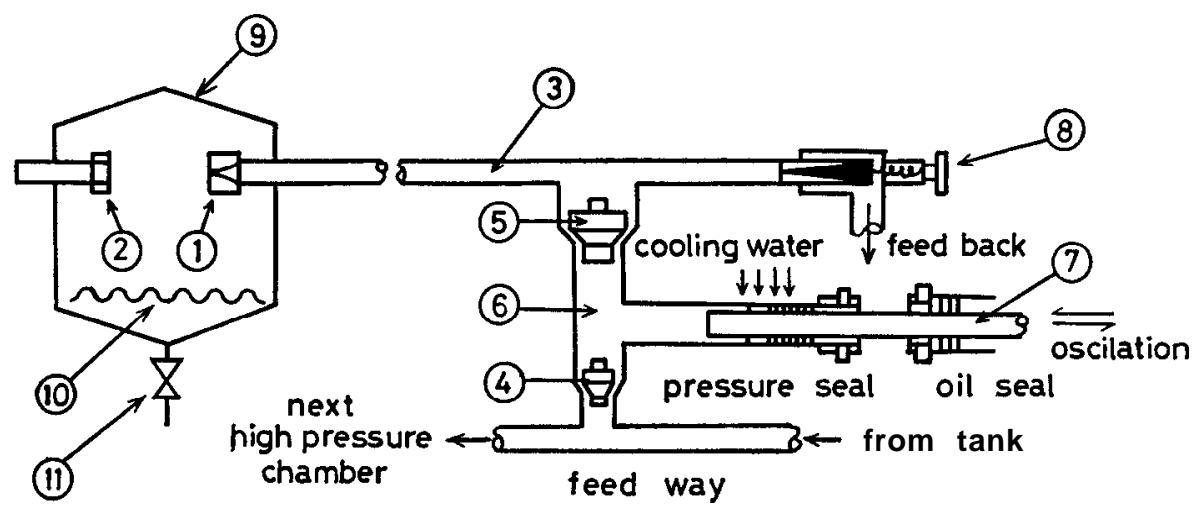

Fig. 1. Diagrammatic sketch of Impact-Cell-Mill.

(1) nozzle (2) disk (3) high-pressure way (4) suction valve (5) discharge valve (6) high-pressure chamber (7) plunger (8) pressure control valve (9) injection tank (10) baffle plate (11) drain 
Calibration of the nozzle in application is $0.35-0.47 \mathrm{~mm}$. The diameter of the nozzle is $0.45 \mathrm{~mm}$ in standard, and the spouting pressure of $600 \mathrm{~kg} / \mathrm{cm}^{2}$, the treatment capacity of single cell suspension is approximately $3 \mathrm{l} / \mathrm{min}$.

\section{Methods of measurement}

Spouting pressure is measured by electromagnetic oscillograph with a pressure gauge, and working condition in high pressure is measured by synchroscope.

The coefficient of discharge is based on the theoretical volume of cylinder and the discharged volume. The temperature is measured by electronic recording controller using a copper constantan thermocouple of $\mathbf{0 . 3} \mathrm{mm}$ caliber.

The measurment of the destruction ratio on a single cell microbe is based on the soluble nitrogen extraction ratio. The treated solution by ICM is centrifuged at $5000 \mathrm{rpm}$ for $15 \mathrm{~min}$ and the supernatant liquid is removed. After washing the precipitate with $0.1 \mathrm{M}, \mathrm{pH} 10.0$ carbonate buffer several times, all washings are mixed with the supernatant liquid and the soluble nitrogen content is measured by micro Kjeldahl method.

The operational conditions of ICM are as follows :

(a) The calibration of a nozzle is $0.45 \mathrm{~mm}$, and a spouting pressure is 600 $\mathrm{kg} / \mathrm{cm}^{2}$. And the clearance between the nozzle and the impulsion disk is $\mathbf{3 0} \mathrm{mm}$.

(b) In the case of the nozzle, the spouting pressure is at $800 \mathrm{~kg} / \mathrm{cm}^{2}$, the calibration of the nozzle is $0.4 \mathrm{~mm}$.

(c) Material of sample is Baker's yeast (Saccharomyces cerevisiae) and concentration of suspension in the operation is 1.62 per cent (dry base).

(d) The diagrammatic illustrations of measuring instruments and a trial nozzle in this study are shown in Fig. 2-Fig. 4.

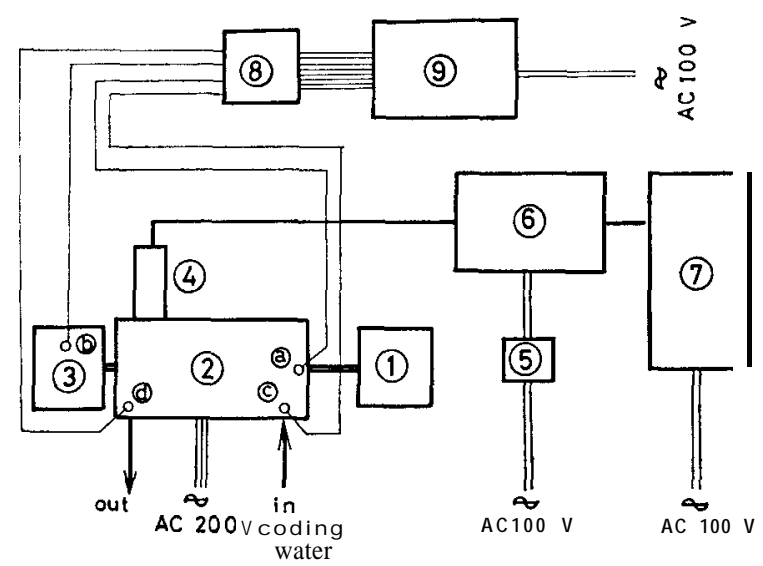

Fig. 2. Diagrammatic sketch of temperature and pressure measuring instrument.

(1) tank (2) Impact-Cell-Mill (body) (3) injection tank (4) pressure gauge (5) electric source of strain meter (6) strain meter (7) recorder (8) cold junction unit (9) electronic recording controller (a) (b) (c) (d) thermoelectric couple 


\section{RESULTS AND DISCUSSION}

The discharged volume of fluid can be shown generally in the following equation. It means that the discharged volume is a function of the spouting pressure.

$$
\mathrm{Q}=\alpha \cdot \mathrm{A} \cdot(2 g h)^{1 / 2}
$$

Q : Discharged volume

$\boldsymbol{g}:$ Gravity conversion factor

$\alpha$ : Discharge coefficient
A : Sectional area of nozzle

h : Head of static pressure

Equation (1) is also function of velocity and exerts influence on the occurrence of spouted potential core which has a direct relation to impact. The relationship between spouting pressure and spouted volume of flow has been considered to determine the operational condition of the machine. The result is shown in Fig. 5. The pressure increasing equipment of trial model three is made of three pairs of suction and discharge valves and one pressure adjustment valve. Structurally even a leakage causes some troubles to make a high pressure. The result of the experiment shows $600 \mathrm{~kg} / \mathrm{cm}^{*}$. Compared with

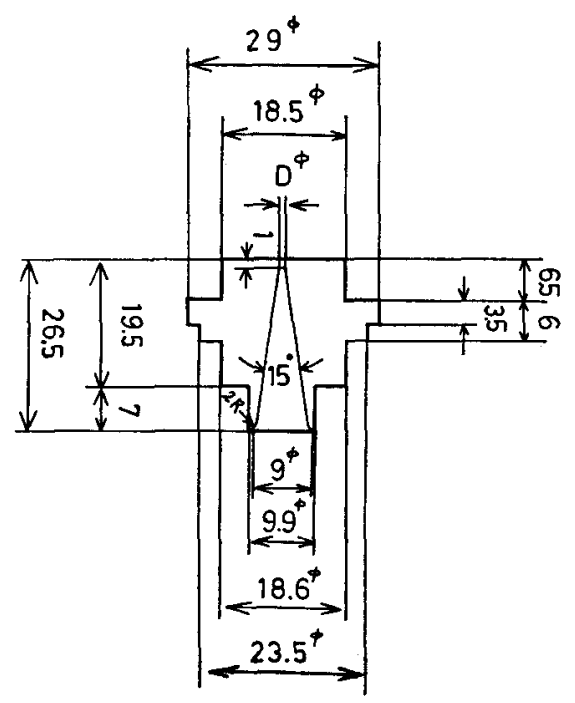

Fig. 3. Drawing of trial nozzle (angle 15 degree>

the theoretical spouted volume $(50.6 \mathrm{ml} / \mathrm{sec})$, the result gives a desirable value of 96.6 per cent. From the above experiment, operational performance is considered to be excellent.

On the increase of the spouting pressure to $800 \mathrm{~kg} / \mathrm{cm}^{2}$, having a nozzle $0.40 \mathrm{~mm}$ in caliber, the result of experiment shows that the spouted volume is $46.7 \mathrm{ml} / \mathrm{sec}$, and the pressure adjustment valve operates effectively, but the motor load is increased up to 150 per cent and is not usable for longer opera- 


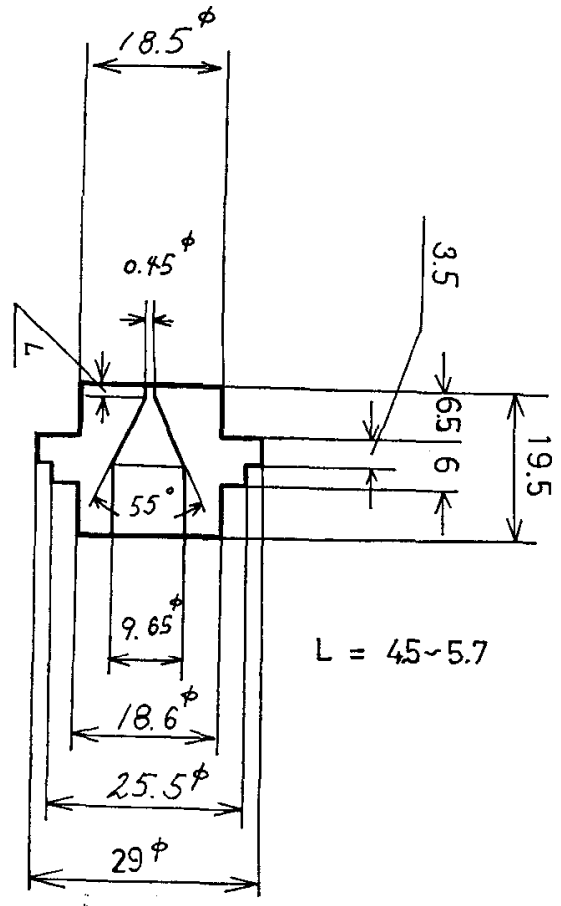

Fig. 4. Drawing of trial nozzle (angle 55 degree).

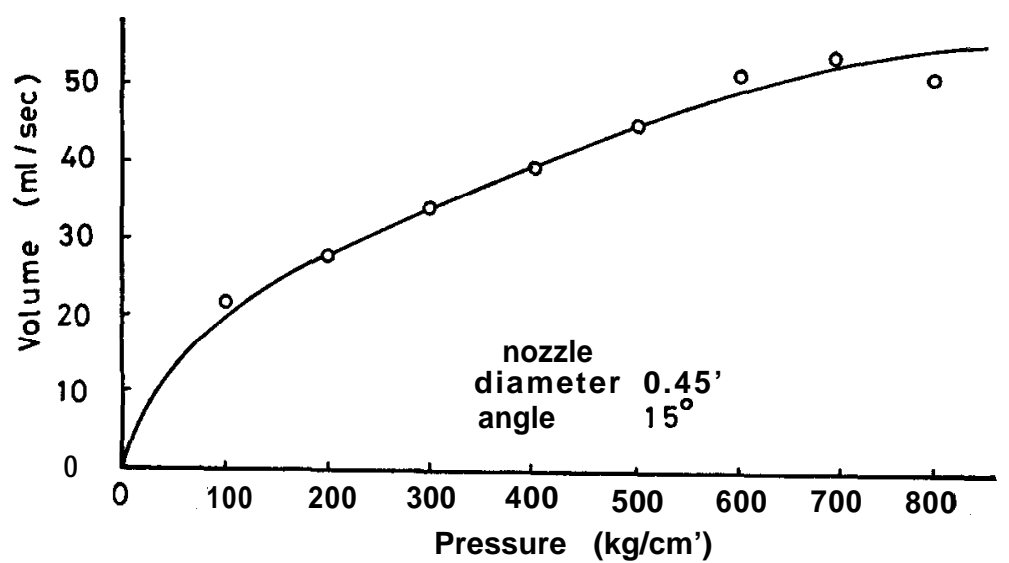

Fig. 5. Relation of spouting pressure and spouted volume.

tion. Based on the result of pre-experiments, teflon and copper are used as packing materials of high pressure units of this trial model. According to this choice of packing materials, durability is improved greatly. Furthermore, replacement of O-ring plunger sea1 unit by $\mathrm{V}$-shape packing, the prevention of leakage at high pressure is effective. 
As a result, the spouted volume of a approx. $3 \mathrm{l} / \mathrm{min}$ enables the application of a continually increased spouting pressure from $600 \mathrm{~kg} / \mathrm{cm}^{2}$ to $800 \mathrm{~kg} /$ $\mathrm{cm}^{2}$. The following experiment is carried out to clarify the input energy conversion and consumption on requirements for industrialization.

Fig. 6 shows a relation between motor input and spouting pressure. As the spouting pressure increases, the spouting velocity also rises. The motor input also rises inevitably as the spouting pressure increases. As a plunger type is used for the pressure addition structure in ICM, Q-H curve of this trial model indicates a direct upward line specific for the constant volume variable type pump such as plunger pump, gear pump, etc., and their input assumes temporarily an upward curve. Input is $3.92 \mathrm{kw}$ when spouting pressure is $600 \mathrm{~kg} / \mathrm{cm}^{2}$.

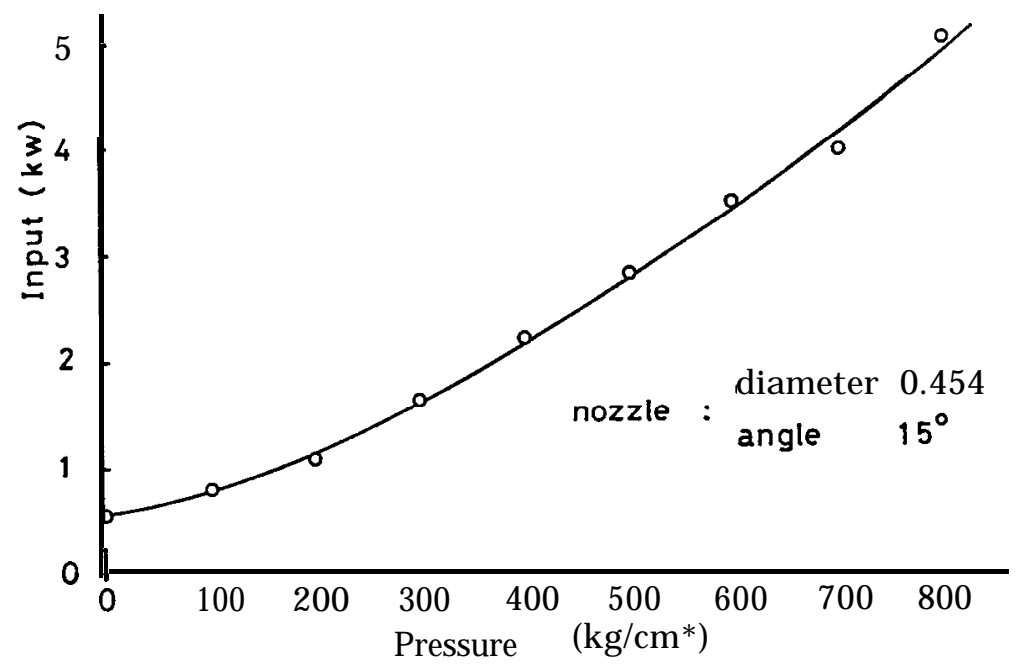

Fig. 6. Relation of spouting pressure and motor input.

Fig. 7 shows a relation between spouting pressure and load based on the value of Fig. 6 and motor charactristic curve. When rated pressure is $600 \mathrm{~kg} /$ $\mathrm{cm}^{2}$, load is approx. 110 per cent. Ten per cent overload is designed to assume the 80 per cent over all efficiency, and causes actual horse power reduction. Load resistance of plunger seal and power units shows 30 per cent, ten per cent greater than the estimated value of twenty per cent. Input shows a variance due to the difference of rock nuts binding of the V-shape packing used in the plunger seals. It means that sealing exerts influence directly on the load.

Conventional high pressure pump is usually capable of discharge pressure of around $300-400 \mathrm{~kg} / \mathrm{cm}^{2}$, and more than $500 \mathrm{~kg} / \mathrm{cm}^{2}$ is exceptional. In this specific device which requires to withstand more than $600 \mathrm{~kg} / \mathrm{cm}^{2}$, the increased frictional resistance is extremely tough on the structure of the sealing and driving units. In the relation as to the number of $\mathrm{V}$-shape packing in use and load (frictional resistance), rock nuts binding are not constant, and steady value 


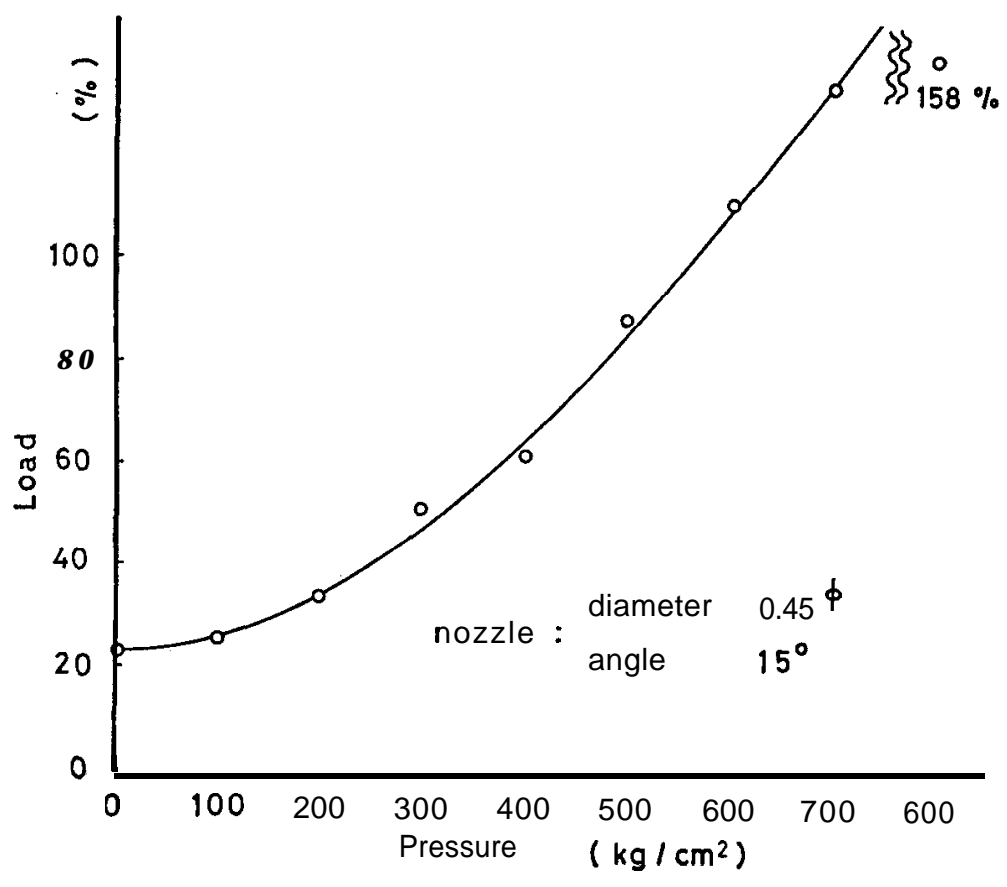

Fig. 7. Relation of spouting pressure and motor load.

is not shown. In the case of two pieces of packing, input decreased until 0.2 $\mathrm{kw}$ under no load condition. Thus, most of load resistance is considered to be dependent on the plunger seal units.

Concerning the durability, packing is damaged and pressure drop occures under the spouting pressure at $600 \mathrm{~kg} / \mathrm{cm}^{2}$ for $30-120 \mathrm{~min}$ of operation. Five pieces of packing used are capable of more than 4000 min of operation. However, once the pressure starts to drop, pressure drop of approx. $100-150 \mathrm{~kg} / \mathrm{cm}^{2}$ can be accelerated. Then, the relationship of nozzle shape and spouting velocity is considered, and the result is shown in Fig. 8 and Table 1.

Discharge coefficient of angle 55 degree's nozzle is a little smaller than that of 15 degree's one. This is due to the difference of nozzle angle and the influence of pressure inside the nozzle. In fact, if the surface antifriction is applied to the nozzle of larger angle, the surface becomes rough compared with that of 15 degree's one.

Chemical treatment of surface abrasion proof of $0.47 \mathrm{~mm}$ in caliber is applied to the nozzle, and the metal surface is turned to be as concave and convex as to have a velvet appearnce. This treatment, on the contrary, decreases a discharge coefficient $(\mathrm{C})$, and shows the minimum value of $\mathrm{C}(0.76)$ among the trial nozzles.

If the roundness $(2 \mathrm{R})$ is applied to the nozzle inlet of the same angle (55 degree's NO. 3), it indicates better result as compared with non-roundness (refer 


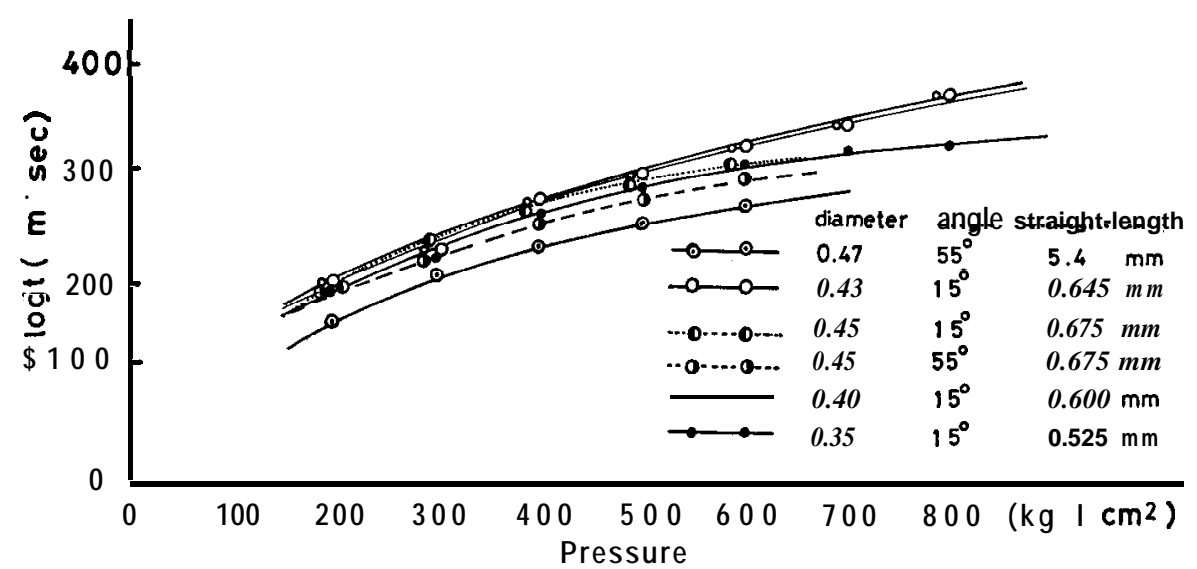

Fig. 8. Relation of spouting pressure and velocity of water jet in each form of 1 trial nozzle.

Table 1. Characteristics data of trial nozzle.

\begin{tabular}{|c|c|c|c|c|c|c|c|}
\hline No. & $\begin{array}{c}\text { 'Diameter } \\
(\mathrm{mm})\end{array}$ & $\begin{array}{l}\text { Velocity } \\
(\mathrm{m} / \mathrm{sec})\end{array}$ & $\begin{array}{l}\text { Coefficient } \\
\text { of flow }\end{array}$ & $\begin{array}{l}\text { Angle } \\
\text { (degree: }\end{array}$ & \multicolumn{2}{|l|}{$\begin{array}{l}\text { Surface } \\
\text { treatment }\end{array}$} & Materials \\
\hline 1 & 0.47 & 261 & 0.76 & 55 & $\begin{array}{l}\text { chemical sur- } \\
\text { face hardening }\end{array}$ & $1.25 \times 10^{4}$ & USA $440 B$ \\
\hline 2 & 0.45 & 274 & 0.80 & 55 & $\begin{array}{l}\text { induction } \\
\text { hardening }\end{array}$ & $1.26 \times 10^{4}$ & USA $440 B$ \\
\hline 3 & 0.45 & 308 & 0.88 & 55 & $\begin{array}{l}\text { non } \\
\text { burnishing }\end{array}$ & $1.39 \times 10^{4}$ & $\begin{array}{l}\text { sintered } \\
\text { hard alloy }\end{array}$ \\
\hline 4 & 0.45 & 308 & 0.90 & 15 & burnishing & $1.42 \times 10^{4}$ & $\begin{array}{l}\text { sintered } \\
\text { hard alloy }\end{array}$ \\
\hline 5 & 0.43 & 325 & 0.94 & 15 & burnishing & $1.43 \times 10^{4}$ & $\begin{array}{l}\text { sintered } \\
\text { hard alloy }\end{array}$ \\
\hline 6 & 0.40 & 325 & 0.94 & 15 & burnishing & $1.43 \times 10^{4}$ & $\begin{array}{l}\text { sinterrd } \\
\text { hard alloy }\end{array}$ \\
\hline 7 & 0.35 & 305 & 0.89 & 15 & burnishing & $1.09 \times 10^{4}$ & $\begin{array}{l}\text { sintered } \\
\text { hard alloy }\end{array}$ \\
\hline
\end{tabular}

to Table 1.). When the spouting pressure is $600 \mathrm{~kg} / \mathrm{cm}^{2}$, Reynold's number (R) of trial nozzle is over ten thousand. When the angle is 15 degree, its $R$ is greater than that of an other angle.

From the results, spouting jet is considered to be in the extreme turbulent zone. The spouting pressure is boosted up to $800 \mathrm{~kg} / \mathrm{cm}^{2}$ in the developed ICM of this research. The average velocity is more than $360 \mathrm{~m} / \mathrm{sec}$ on the spouting jet of single cell microbe suspension. The kinetic energy of the jet reaches $3.28 \times 10^{2} \mathrm{~kg}-\mathrm{m} / \mathrm{sec}(767 \mathrm{cal} / \mathrm{sec})$. Moreover, spouting jet requires high pressure as described before, and it can be ejected from extremely minor nozzle. Therefore further examination is needed as to abrasion of metal material and also to the structural parts such as the impact disk, inside the nozzle, valve surface and so on. 
Fig. 9 and Table 2. show the results of experiments as to abrasion of nozzle and valve surface. After treating yeast suspension of approx. 200 liters with the nozzle (No. 3) applied chemical antiabrasion treatment, surface coating is extinguished, $440 \mathrm{~B}$ ground metal is come into view and the abrasion is accelerated.

As to the induction hardening nozzle (No. 2), it can endure 630 liters, three times as much as that operated by chemical treatment, but can not be perfect.

However, as to sintered hard alloy nozzle (No. 1), durability has been improved. When yeast suspension was treated about 1500 liters, increasing rate of abrasion is about four per cent in the diameter of nozzle $(0.45 \mathrm{~mm})$.

It has become apparent in Table 2. of SUS 27 stainless-made-valve is about 800 liters (about 5 hours) and sintered hard alloy is desirable for the material.

With a view to the utilization of hard material, ceramics is used for the impact disk for a while. Hardness value indicates 93.1 of Rockwell A scale, and the treatment capacity of yeast suspension is only 1.5 liters, and its value is about $1 / 2 \times 10^{4}$ of sintered hard alloy's durability (about 200 hours). That is due to corrosion of ceramics surface by strong water jet. Cohesion of ceramics molecule is considered to be weaker than that of sintered hard alloy. This study provided conclusive proof that sintered hard alloy is desirable for both nozzle and disk.

The basic structure of single cell destruction in ICM consists of utilizing impact power, and greater impact power is needed for the improvement of

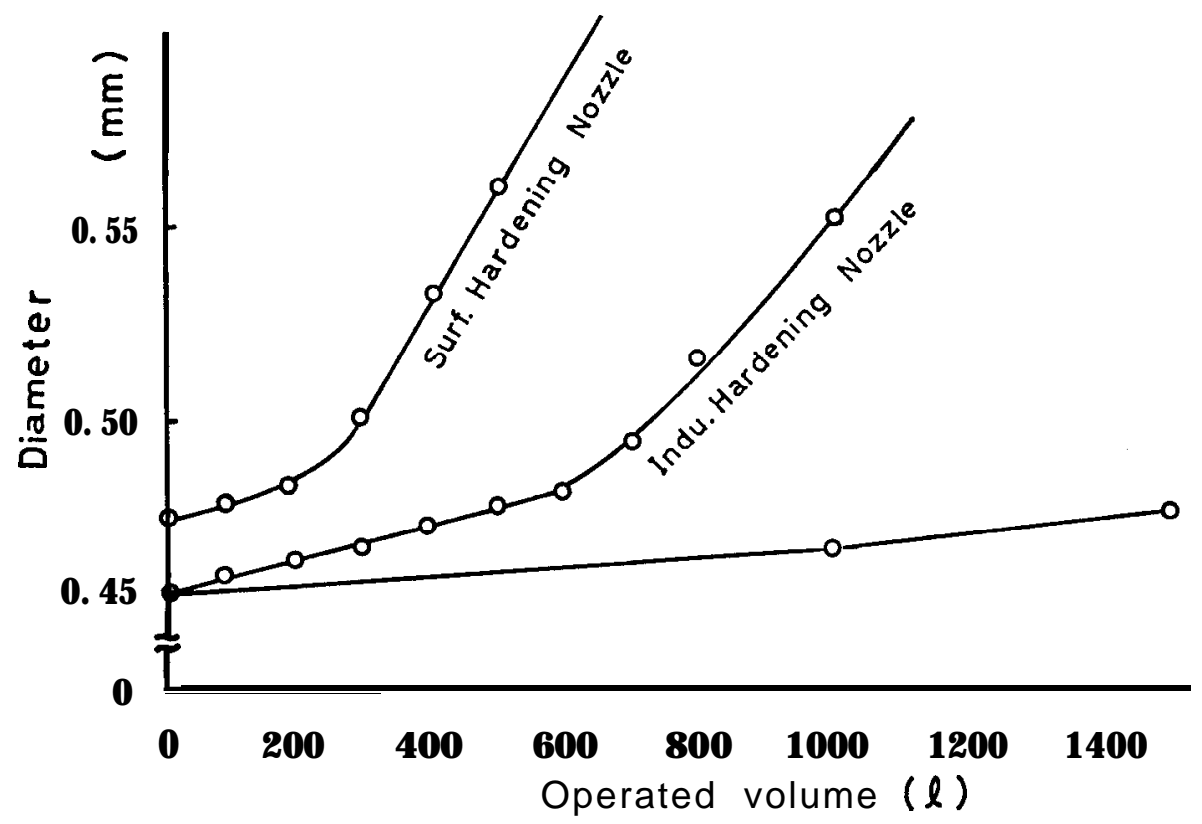

Fig. 9. Relation of operated volume and durability of nozzle materials. 
Table 2. Durability of materials.

\begin{tabular}{|c|c|c|c|c|c|}
\hline \multirow{2}{*}{$\mathrm{N}$ a m e } & \multirow{2}{*}{ No . } & \multirow{2}{*}{ Materials } & \multicolumn{2}{|c|}{ Hardness } & \multirow{2}{*}{$\begin{array}{c}\text { Critical operated } \\
\text { volume (I) }\end{array}$} \\
\hline & & & $\begin{array}{l}\text { Rockwell } \\
\text { A scale }\end{array}$ & $\begin{array}{l}\text { Vicker's } \\
300 \mathrm{~g}\end{array}$ & \\
\hline Nozzle & 1 & Sintered hard alloy & 92.4 & 1292 & 1500 \\
\hline Nozzle & 2 & $\begin{array}{l}\text { USA 440B: induction } \\
\text { hardening }\end{array}$ & 69.8 & 417 & 600 \\
\hline Nozzle & 3 & $\begin{array}{l}\text { USA 440B: chemical } \\
\text { surface hardening }\end{array}$ & 57.7 & 1180 & 200 \\
\hline Disk & 1 & Sintered hard alloy & 91.5 & 1200 & 1500 \\
\hline Disk & 2 & Stellite & 69.1 & 471 & 800 \\
\hline Disk & 3 & $\begin{array}{l}\text { USA 440B: induction } \\
\text { hardening }\end{array}$ & 73.1 & 447.3 & $500-800$ \\
\hline Disk & 4 & Ceramics & 93.1 & - & 150 \\
\hline Disk & 5 & $\begin{array}{l}\text { Sintered hard alloy } \\
\text { coating }\end{array}$ & 92.5 & $750-1003$ & $0.1-0.2$ \\
\hline Valve & & SUS 27 & 57.8 & 201 & 800 \\
\hline Valve sl & heet & sus 27 & 57.8 & 201 & 800 \\
\hline Plunger & & sus 27 & 57.8 & 201 & above 20000 \\
\hline Cylinder & & sus 27 & 57.8 & 201 & above 20000 \\
\hline
\end{tabular}

destruction coefficient. Therefore it is provided a spouting pressure with maximum kinetic energy and which is required to stop instantly. When it is stopped, impacted kinetic energy may be almost converted to heat which partly changes to sound, device vibration, and destruction of single cell microbe.

We have measured the temperature rising of yeast suspension by impact, because we required to determine the input energy conversion to calculate the destruction energy of single cell microbe. Fig. 10 shows a result of an experiment under the conditions : (a) room temperature ; 21 " $\mathrm{C}$, (b) temperature of yeast suspension ; $13{ }^{\circ} \mathrm{C}$, (c) temperature of cooling water $; 12{ }^{\circ} \mathrm{C}$, (d) concentration of yeast suspension; 1.62 per cent. The temperature of the treated fluid varies linearly with an increase of spouting pressure.

When treated at one time on a spouting pressure of $600 \mathrm{~kg} / \mathrm{cm}^{2}$, temperature rises from $13{ }^{\circ} \mathrm{C}$ to 32.4 " $\mathrm{C}$. However, this trial model is inefficient in the heat shelter, because 'heat inflow from the surrounding device is present. So the temperature is considered to rise up a little until the fluid receives impact. Thus, heat inflow per hour is constant. In Fig. $10,18{ }^{\circ} \mathrm{C}$ can be obtained with extapolation a spouting pressure at $0 \mathrm{~kg} / \mathrm{cm}^{2}$. When the assumed temperature of yeast suspension rises from $13{ }^{\circ} \mathrm{C}$ to $18{ }^{\circ} \mathrm{C}$ before impact by the heat conduction, convection and radiation through the device. The real increasing temperature is $10.1{ }^{\circ} \mathrm{C}$ under the treatment of spouting pressure $600 \mathrm{~kg} / \mathrm{cm}^{2}$ and $14.4^{\circ} \mathrm{C}$ under $800 \mathrm{~kg} / \mathrm{cm}^{2}$. 


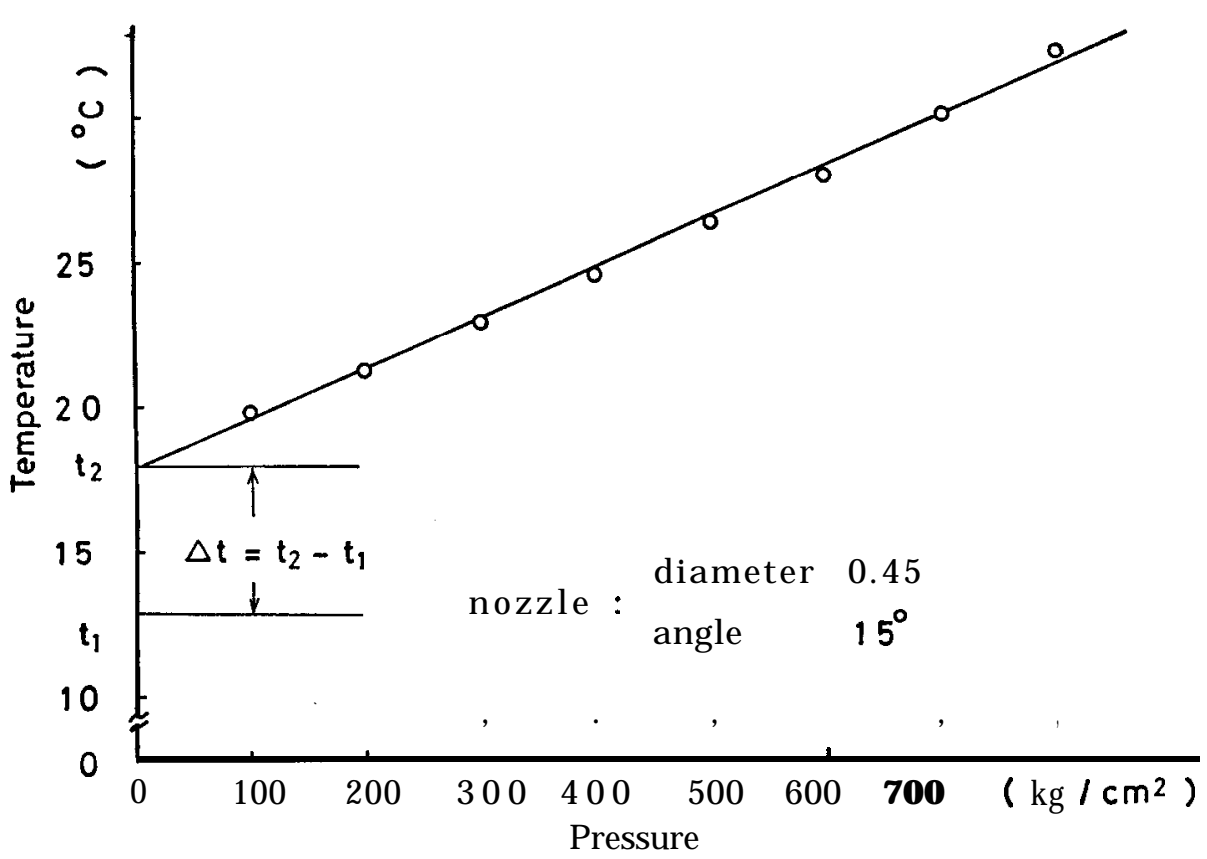

Fig. 10. Relation of spouting pressure and temperature increasing.

Assuming that the heat capacity of yeast suspension is $1 \mathrm{cal} / \mathrm{g}$ " $\mathrm{C}$, the quantity of generated heat $(\mathrm{Q}$, cal) may be calculated from the spouted volume and real increased temperature $(\Delta \mathrm{t})$. Since the temperature of the inside of the injection tank rises higher than the ambient temperature of the device, heat loss will take place. In oder to calculate the heat loss quantity $\left(Q_{2}\right.$ cal) from the injection tank, we assume that the conductivity of the material is 21.5 $\mathrm{kcal} / \mathrm{m}^{2} \mathrm{hr}$ " $\mathrm{C} / \mathrm{m}, \mathrm{Q}_{1}+\mathrm{Q}_{2}=\mathrm{Q}$ is full calorific value from the spouted impact jet. As shown above, the kinetic energy of injection is shown by $\mathrm{E}=1 / 2 \mathrm{MV}^{2}$, kinetic energies (Qj cal) at each spouting pressure are calculatd. The values Qj and $Q$ are shown in Fig. 11.

A parameter, $E=Q / Q j$ represents a heat conversion ratio by impact in Fig. 12. Actually, almost all kinetic enrgy of spouted jet can be converted to heat. On the experiment when spouting pressure is low, heat conversion ratio and generated value of heat show a lower value. The quantity of generated heat is directly proportional to the kinetic energy of injection. Since the weight of this trial machine is approx. $500 \mathrm{~kg}$, most of the real-generated heat can be transferred to the device instantly. It causes a great measurement error in case of low generated heat.

When the remaining of single cell microbe destruction is assumed using heat conversion ratio 93.8 per cent on the treatment of spouting pressure at $800 \mathrm{~kg} / \mathrm{cm}^{2}$, single cell destruction energy is calculated by the following equation (2). 


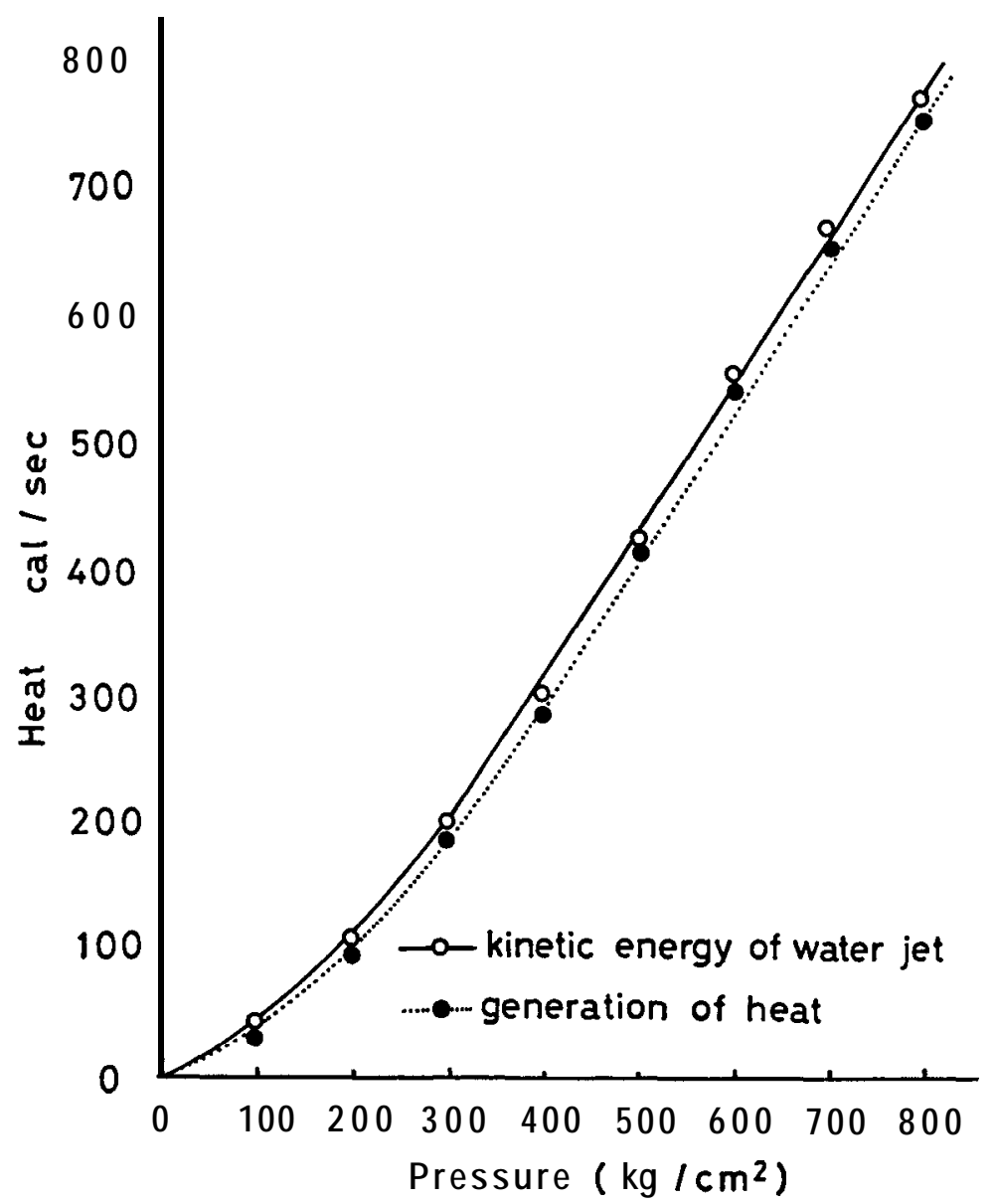

Fig. 11. Relation of spouting pressure and generation of heat.

$$
E=\left\{1-\frac{2 g_{c} \cdot(\Delta t \cdot \gamma \cdot Q+q)}{234 \cdot Q \cdot V^{2}}\right\}\left(\frac{234 \gamma \cdot Q \cdot V^{2}}{2 g_{c} \cdot Q \cdot C \cdot \eta}\right)
$$

Q : spouted volume (g/see).

$\gamma$ : density of suspension ( $\mathrm{g} / \mathrm{cm}$ ").

4 : loss quantity of heat (cal/sec).

$\eta$ : destruction ratio of single cell microbe (per cent).

$C$ : concentation of suspension $\left(\mathrm{g} / \mathrm{cm}^{\prime}\right)$.

$V$ : spouted velocity $(\mathrm{cm} / \mathrm{sec})$.

$g_{c}$ : gravity conversion coefficient (kg-m/Kg-set).

If we have Baker's yeast as an example, the destruction energy per gram of yeast is calculated as follows ;

(a) the concentration of suspension is 1.62 per cent.

(b) the caliber of nozzle is $0.45 \mathrm{~mm}$. 


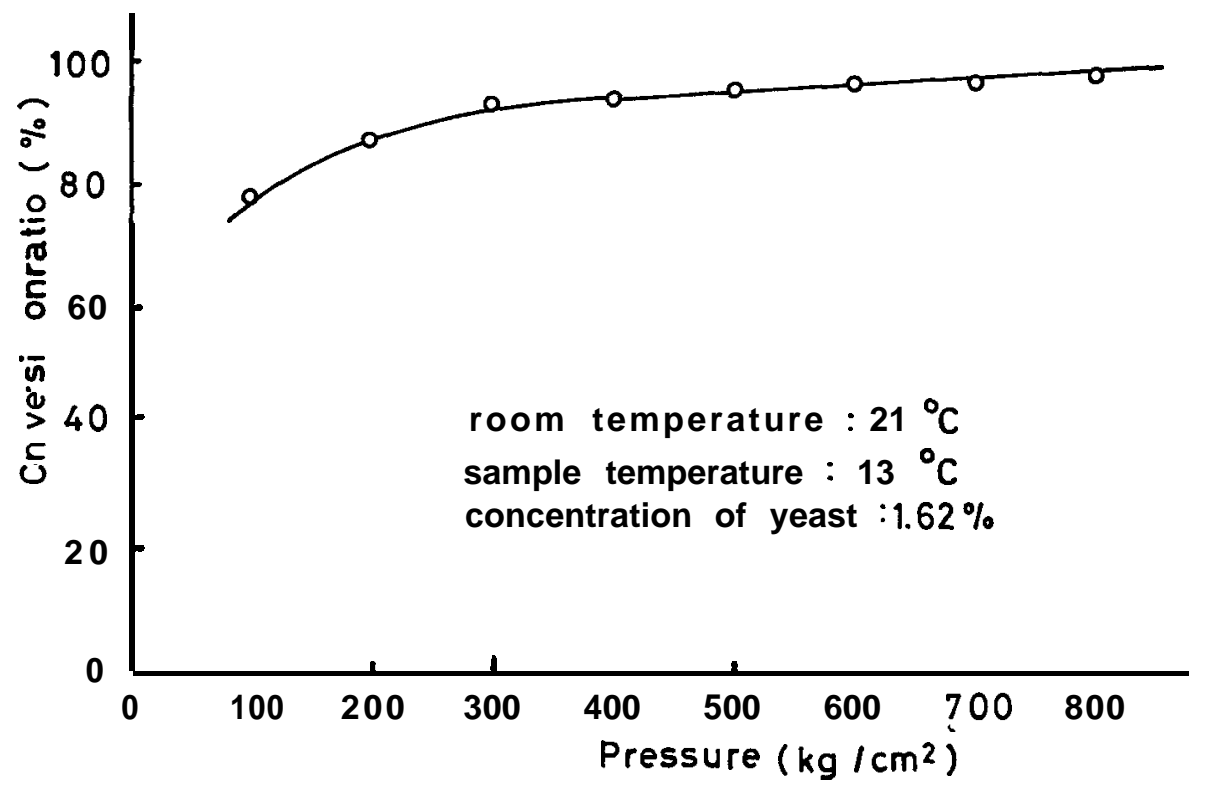

Fig. 12. Relation of spouting pressure and heat conversion ratio of kinetic energy of water jet.

(c) spouting pressure is $600 \mathrm{~kg} / \mathrm{cm}^{2}$.

(d) the destruction ratio is 34.1 per cent.

and

(a) the concentration of suspension is 1.62 per cent.

(b) the caliber of nozzle is $0.40 \mathrm{~mm}$.

(c) spouting pressure is $800 \mathrm{~kg} / \mathrm{cm}^{2}$.

(d) the destuction ratio is 44.8 per cent.

From these values, the destruction energy of Baker's yeast cell can be determined as $24.3 \mathrm{cal} / \mathrm{g}$ at the pressure of $600 \mathrm{~kg} / \mathrm{cm}^{2}$, and $26.6 \mathrm{cal} / \mathrm{g}$ at the pressure of $800 \mathrm{~kg} / \mathrm{cm}^{2}$.

If the viscosity and quantity of yeast suspension are less in value compared with those of water, the higher the concentration of yeast suspension, the less the operational expenses and destruction energy will be required.

\section{CONCLUSION}

On the improvement of trial model of Impact-Cell-Mill (ICM) which destructs single cell microbe like yeast in a suspension, the following conclusions are obtained.

1) Teflon is the best for the seal packing material of each unit, and the usage of more than 4 sheets of $\mathrm{V}$-shape packing is desirable regarding durability.

2) Following relationship exists between the spouting pressure and the temperature increasing on input and treated suspension. 


$$
W=(P / 150)+0.92 \quad \mathrm{t}=(4.1 / 300) P+18
$$

$\mathrm{W}$ : input $(\mathrm{kw}), \mathrm{P}$ : spouting pressure $\left(\mathrm{kg} / \mathrm{cm}^{2}\right)$

$\mathrm{t}$ : temperature (degree "C)

3) Sintered hard alloy is suitable for the material of nozzle, disk and some valves.

4) When Baker's yeast is treated one time with ICM under spouting pressure at $600-800 \mathrm{~kg} / \mathrm{cm}^{2}$, the destruction ratio is $34-44$ per cent. And the destruction energy is $24-26 \mathrm{cal} / \mathrm{g}$.

\section{REFERENCES}

Fujita, S., S. Ito, T. Otake, D. Kunii, B. Shirata, R. Doei, T. Mizushina, T. Miyauchi, and R. Mori, 1968 KAGAKUKOGAKU BENRAN. Maruzen, Tokyo

Humphrey, A. E. 1969 Engineering of single cell protein. In "Engineering of unconventional protein production", ed. by Herman Bieber, American Institute of Chemical Engineers, New York, pp. 60-71

Kurosawa, K. 1969 Engineering for production of petroleum yeast protein. SEKIYU TO SEKIYUK AG AKU, 13:102-107

Laine, B. 1967 Production and Utilization of BP Protein Concentration. In "Text of a Paper Presented at the Second International Conference on Global Impacts of Applied Microbiology”, ed. by Bernard Laine, Laboratory of Microbiology, S. F. BP, Lavera (France), pp. 1-18

Mitsuda, H., F. Kawai, R. Mibu, and T. Shikanai, 1964 Isolation of Protein from Torula Yeast. J. Jap. Soc, Food and Nutrition, 17: 342-346

Mitsuda, H., K. Yasumoto, and T. Furukawa, 1967 Protein isolates from glutamic accumulating bacteria. J. Jap. Soc. Food and Nutrition, 20: 40-44

Miwa, S. and Y. Kosaka, 1971 Study of Mill and Milling Methods, KAGAKUKOGAKU, 35: 290-294

Okuda, S. 1971 Mills of Fluid Energy Utilization. KAGAKUKOGAKU, 35: 294-298

Yamada, K. 1968 Production of Protein. SEKIYU TO SEKIYUKAGAKU, 13: 41-48 